\title{
FEMALE POWER THAT PROTECTS: WHO IS THE WOMAN WHO TAKES CARE OF THE CITY? GODDESS PROTECTRESSES ON THE TERRITORY OF THE CENTRAL BALKANS IN LATE ANTIQUITY
}

\begin{abstract}
Although many ancient goddesses, like Athens, Artemis, Nemesis and Aphrodite, as well as Isis and Cybele had the function of protecting the city, in the period of Late Antiquity, the Greek Tyche and Roman Fortuna were the ultimate protectresses of the city. On the territory of the Central Balkans, their important role during Late Antiquity can be equated with the instability of this region due to the constant barbaric Hun attacks and the permanent need of the people who had lived here for the protection and good fortune of their cities and land.
\end{abstract}

KEYWORDS: GODDESS PROTECTRESSES, TYCHE, FORTUNA, CENTRAL BALKANS, LATE ANTIQUITY.

\section{INTRODUCTION $^{1}$}

In the period of the Late Antiquity, the population of the Central Balkans region worshiped various divinities, with the most popular goddesses being of Greco-Roman or Eastern origin. Archaeological material confirms the important protective functions of some pagan goddesses that remained dominant not only in the period after the Edict of Milan, but also in the time of Justinian's reign, when pagan cults were forbidden but still present in popular motifs and during their trans-

1 The article results from the project: Viminacium, Roman city and military camp - research of the material and non material culture of inhabitants by using the modern technologies of remote detection, geophysics, GIS, digitalization and $3 D$ visualization (no 47018), funded by The Ministry of Education, Science and Technological Development of the Republic of Serbia. formation into Christian symbols. Many aspects of the worship of these divinities were changed by historical circumstances. On one hand, it is very hard to follow the path of certain cults, due to the barbaric attacks of the Huns from 441 to 443, while on the other hand, the mentioned historical background induced a more tangible popularity of female deities with protective functions.

On the central Balkans territory, during the antiquity period, Greek cults were mostly transferred via trade routes, and among the most popular goddesses were: Hera, Artemis, Hestia, Aphrodite, Ananke, Hecate and Nemesis (Марић 2003: 5377). The representations of Greek goddesses, as well as their Roman equivalents, were mostly rendered in accordance with their Greek models and, in the period between the 4th and 6th centuries, they allow an insight into the popularity of certain 
cults within the visual culture of religious syncretism and the rise of Christianity in Roman society.

During the Antiquity period, many goddesses, such as Athena, Artemis, Nemesis, Cybele and Isis were worshiped as protectresses of the city, but the most popular goddess, honoured as the one who guards and reigns over the boundaries and the fate of the city and the people in it, was the Greek goddess Tyche, or her Roman equivalent, Fortuna (Luyster 1965: 133-163; McCown 19311932: 131-134, 138).

Since almost every Greek, and later Roman, city had its own Tyche, i.e. Fortuna, the cults of these deities were widely accepted and, thus, very popular all over the Roman Empire ( $C f$. Matheson, Pollitt 1994). The goddess Tyche (Fortuna) is usually represented as a seated or standing female figure, with the so-called mural crown, a crown in the shape of the city walls (corona muralis), on her head, holding different attributes like a cornucopia (frequently with fruits), a ship's rudder, a wheel of fortune, a globe, the horn of Amalthea, ears of grain etc. Sometimes, she is represented blind-folded and carrying the infant Ploutos. In the period of Late Antiquity, goddess protectresses of cities like Alexandria, Antioch, Trier, Rome and Constantinopolis, were depicted in calendar iconography (for the year 354), with decorations of silver handles of Esquiline treasure, consular ivory diptychs etc. ${ }^{2}$

\section{GODDESS PROTECTRESSES ON THE TERRITORY OF THE CENTRAL BALKANS IN LATE ANTIQUITY}

One of the interesting presentations of the goddess Tyche was found on the territory of present day Serbia, within the imperial palace at Sirmium, and is dated to the $4^{\text {th }}$ century (Popovic 2008: 159-162, Fig. 4; Popović 2009a: 269-270, Fig. 2; Popović 2009b: 452; Popović 2012: 58-60, kat.

2 More about this visual material in: Bertelli 1999: 129131; Toynbee 1947: 135-144; Grig 2012: 31-52.

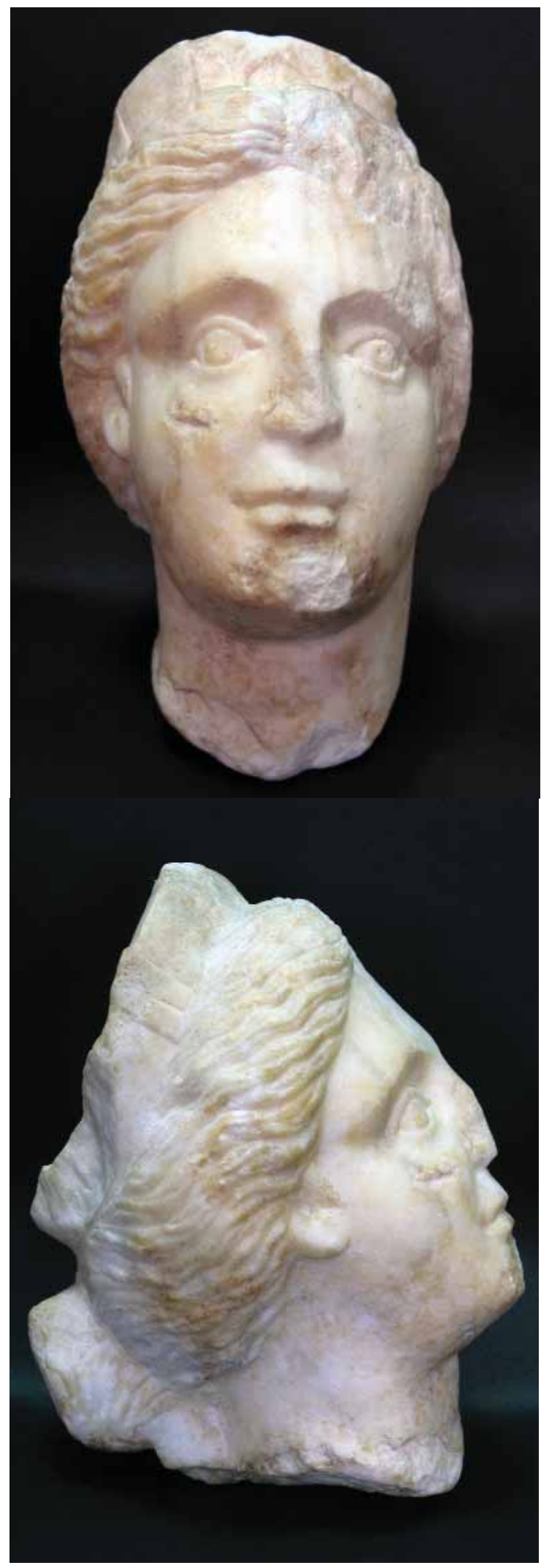

Fig. 1: Head of the Sirmium's Tyche (documentation of the Institute of Archaeology) 


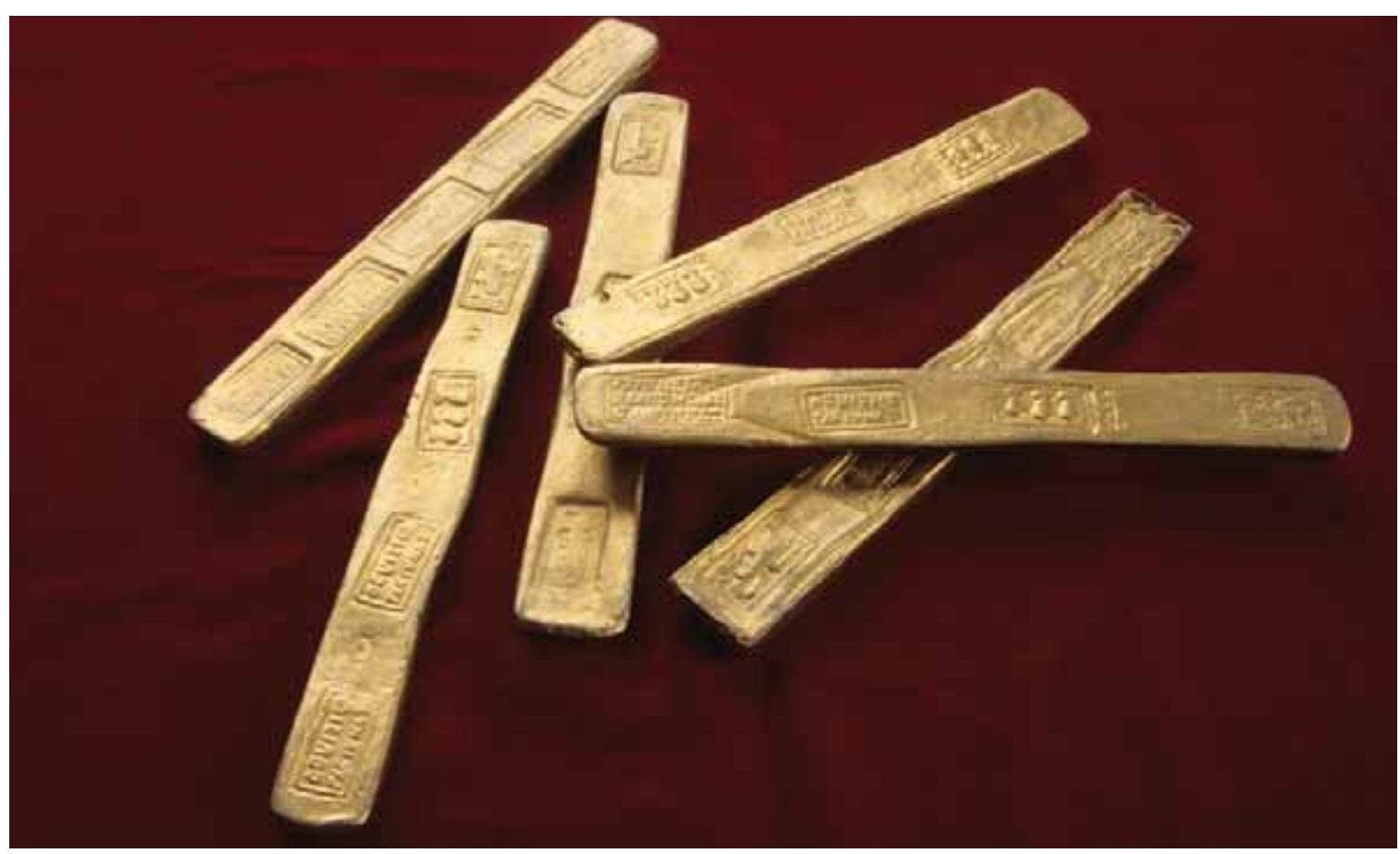

Fig. 2: Gold ingots from the site of Crasna, with the representation of Sirmium's Tyche (documentation of the Institute of Archaeology).

36, sl. 36a-c; Jeremić 2009: 489-490, 495, Fig. 27). It is a fragmented marble head of a mature woman, slightly inclined backwards (Fig. 1). The face of the woman has a gentle expression; the facial features are softly and carefully modelled, yet without individual portrait characteristics. The eyes are emphasised and the shape of the woman's lips suggests a slight smile, while the nose and the top of the chin are damaged. The coiffure, parted in the middle, is modelled with gentle waves, thus surrounding the face, while on the back of the head the hair is gathered into a bun. The treatment of the woman's face and her coiffure are characteristic of representations of Roman empresses and women in the $4^{\text {th }}$ century (Petkovic et al. 2015: 81-83). On the top of the woman's head is a crown, and its appearance is similar to a corona muralis, the type of crown characteristic of god- desses who protected and ensured the fortune and prosperity of the city (Анђелковић et al. 2013: 388-389). ${ }^{3}$ The symbol of the corona muralis is of great importance for the identification of the goddess in question, from Sirmium, and it probably belonged to a standing or seated sculpture. ${ }^{4}$ The statue of the Sirmium goddess was possibly located near the finding place of the head, in the niche above the entrance to the imperial palace complex,

3 Bust of the goddess, made of bronze, from Ravna is dated in the period of the $2^{\text {nd }}$ and $3^{\text {rd }}$ century. On her head is represented corona muralis, atribute that identified her as city protectress - Тусhе. Петровић, Јовановић 1977: 86. кат. 4; Vulić 1941-48: 49, бр. 206.

4 The motif of corona muralis on the head of goddess, unlike the high, cylindrical crowns with accentuated forms of city walls known from representations of Tyche of Alexandria or Antioch, here is lower and reduced on concave and convex forms that only suggest the impression of city walls. Popović 2008: 159, 161; Popović 2012: 110-112, kat. 36.

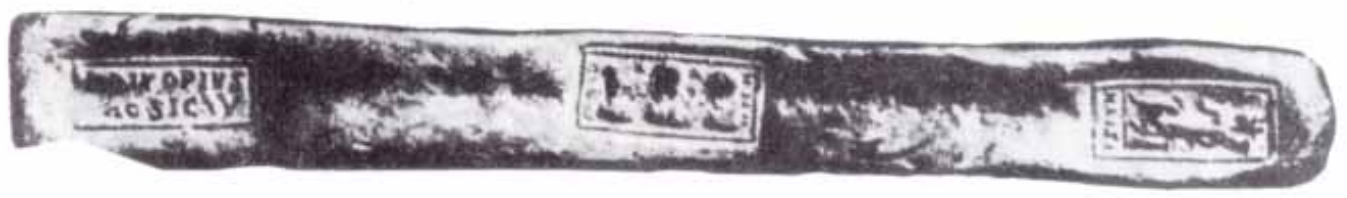

Fig. 3: Tyche of Naissus, on a gold ingot from the site of Feldioara-Bod (after: Дрча, кат. 196, 2004). 


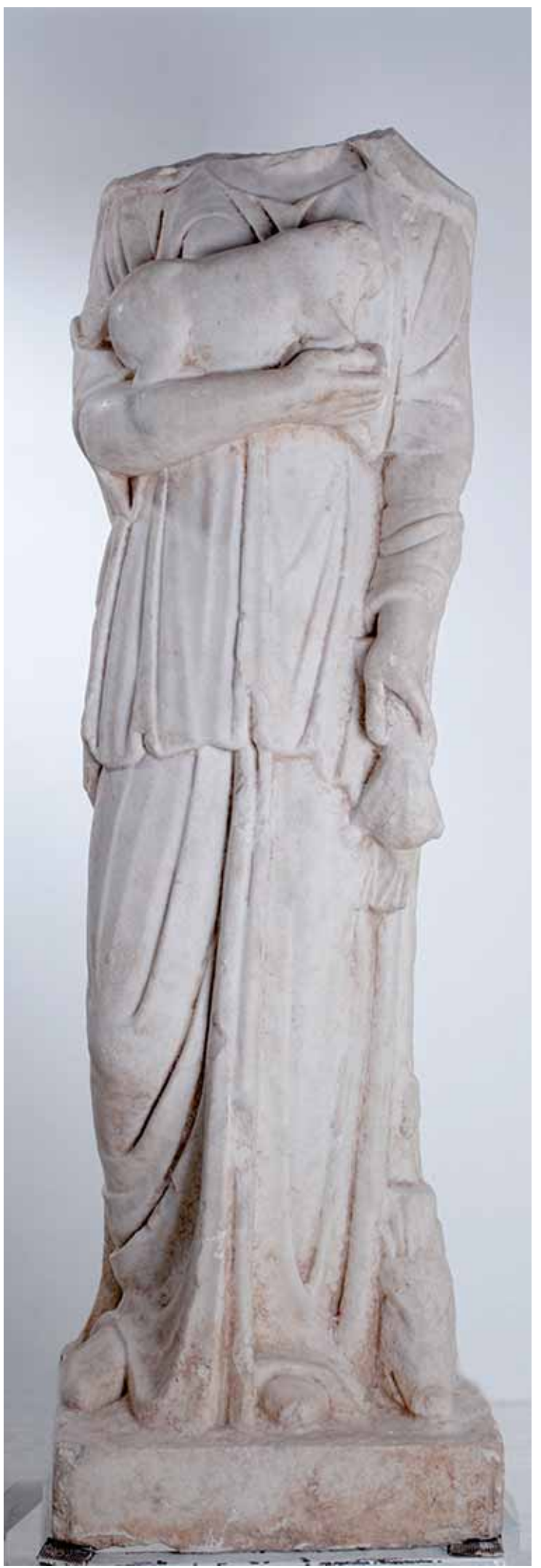

Fig. 4: The statue of Dea Dardanica (documentation of the National Museum Niš). where the sculpture of the goddess was placed as a symbol of the identification of the palace with the city, i.e. "city inside of the city" (Jeremic 2009: 495). Besides this find, two more representations of female figures, carved on gold bars, from the site of Crasna, near Brashov, in Romania, dated to the last quarter of the $4^{\text {th }}$ century, were identified as Sirmium's Tyche (Fig. 2) . On both depictions there is schematically rendered seated figure of a woman presented in profile, holding a palm branch and cornucopiae in her hands, while on her head is a mural crown. On both, there are stamps with the inscription SIRM, which allows the identification of these representations as city protectresses, analogous to similar representations on gold bars from Rome, Thessaloniki, Naissus and Constantinople, dated to the end of the $4^{\text {th }}$, or the beginning of the $5^{\text {th }}$ century (Mundell Mango 1992: 205-206, Fig. 2a-f; Baratte 1978: 107-108).

Tyche of Naissus is depicted on a gold bar from the site of Feldioara-Bod, near Brasov, in Romania, which is dated to the second half of the $4^{\text {th }}$ century (Fig. 3). ${ }^{6}$ The Naissus city protectress is depicted seated on the throne, dressed in a long chiton, with a himation placed over her shoulders, a mural crown on her head, an olive branch in the right hand and cornucopiae in her left. Beneath the goddess, on the throne base, there is the inscription NAISI.

The female personification of the homeland of the Dardanians, Dea Dardanica, is presented in a statue discovered in 1933, during excavations of the residential complex of Mediana, near Niš (Jovanović 1980: 53-60, сл. 1; Srejović, Cermanović-Kuzmanović 1987: 134, kat. 58; Tomović 1992: 94, cat. 95, Fig. 28/3; Петровић 1993: 78; Дрча 2004, кат. 70; Поповић 2008: 31-32, сл. 1-1а; Љубомировић 2014: 738-739, сл. 5). The

5 Dating is suggested by representations of three busts, probably of emperors Gratian, Valentinian II and Theodosius, represented on one of these two bars. Popović 2008: 159-160, Fig. 5a-b.

6 As is the case with the Tyche of Sirmium, dating is suggested by three busts of emperors in medallions, probably Gratian, Theodosius I and Valentinian II. Дрча 1993, кат. 1, сл. 1; Дрча 2004, кат. 196. 

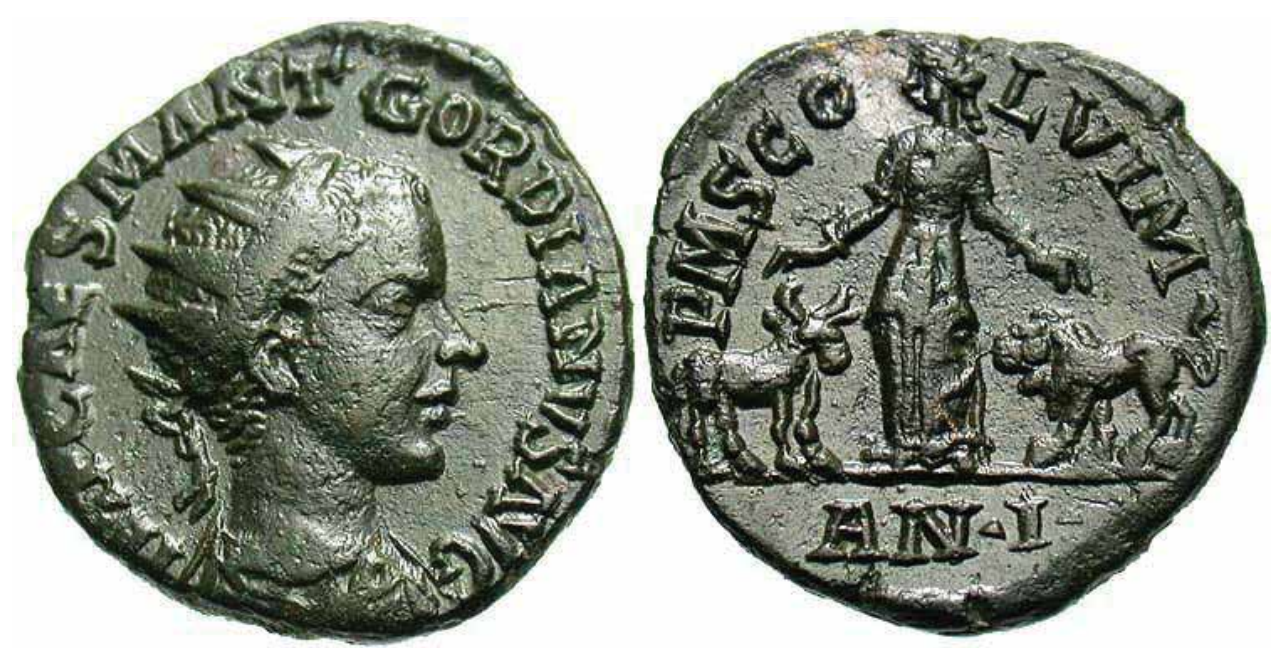

Fig. 5: Personification of the province Moesia Superior on the reverse of coins minted in Viminacium (source: http://www.cnvaldostano.it/la_zecca_di_viminacium.htm\#_ftn17, accessed: 15.5.2015).

sculpture represents a woman dressed in a long chiton and short himation (Fig. 4). Unfortunately, the sculpture's head is missing, but it can be presumed that she wore a veil on her head, since traces are visible on the woman's shoulders and from where the veil runs over her back and finishes near her feet. The weight of the woman's body is on her left leg, while her right leg is moved slightly backward. Her right arm is bent at the elbow and placed on her chest and in her right hand the woman holds a small figure of an ox, while in her left hand she holds a bag of money (marsupium). Beside her left feet, the head of a wild boar and a double-edged axe (labrys) are presented. Analysis of the goddess' attributes has determined that the animals symbolise cattle breeding and hunting, while the money bag implies mining and the wealth of the province for which the goddess was protectress - ancient Dardania. As the main deity (dea patriae) of Dardania, Dea Dardanica was the protectress not only of the province and the people, but also of nature, animals and natural resources. The stylistic characteristics of the sculpture point to the period from the second half of the $3^{\text {rd }}$ to the early $4^{\text {th }}$ century $(C f$. Tomovic 1992 , cat. 95; Поповић 2008: 31, peф. 2-5). Other existing analogies for the statue of Dea Dardania show that the representations of the personification of Dardania were not only associated with the prov- ince itself, but also with the wider region that the Dardanians inhabited (Поповић 2008: 32-40; $C f$. Dobruna-Salihu 2013: 217-224.). Also, it is important to emphasise that the context in which the the statue of Dea Dardania was found, near the entrance of the villa with peristyle in Mediana, clearly shows that the sculpture carried a deeper, ideological meaning. Located at the very entrance of the residential palatial complex of the emperor Constantine the Great, the statue of Dea Dardania, the dea patria of the emperor himself, was protecting not only him and his family, but also the Roman state and its people (Васић 2013: 100).

Therefore, it can be assumed that the placing of the statue of Dea Dardania at the very entrance of the villa with peristyle in Mediana, and possible placing of the statue of the Sirmium Tyche not far from the assumed entrance to the residential complex in Sirmium, confirm the placing of goddess protectresses at the entrances of imperial complexes, to guard the emperor, his family and thus, the state and the people in it.

Iconographic representations associated with the protectress of Moesia Superior or its capital city Viminacium, are preserved on the reverse of coins minted in Viminacium during the period between $239-240$ and $254-255,{ }^{7}$ as well as in the

7 A representation of the province on the reverse side of coins can sometimes be depicted with symbols of branches or a globe, the whole scene is surrounded with the title 


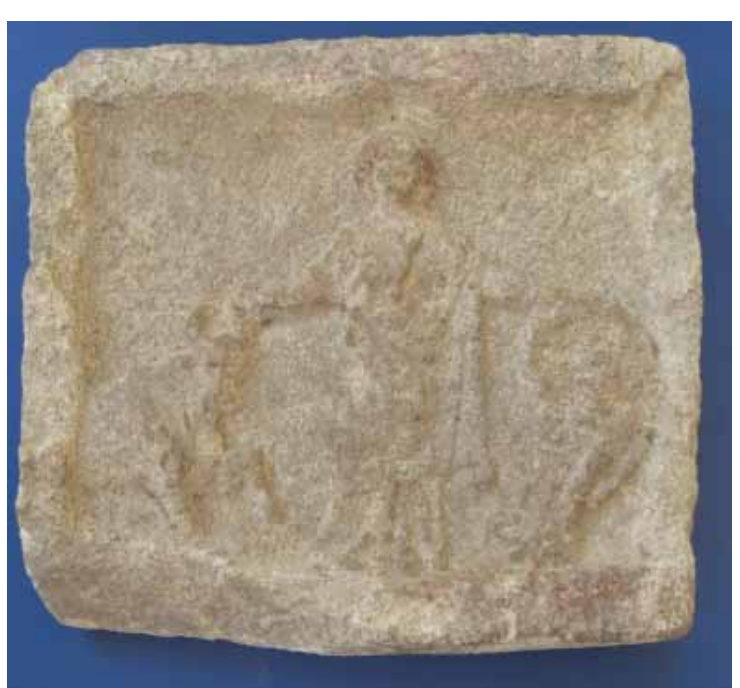

Fig. 6: Relief with the personification of the province Moesia Superior (documentation of the National Museum Požarevac).

relief at the National Museum in Požarevac (Figs. 5 and 6). ${ }^{8}$ The representation of the goddess in the relief shows a woman dressed in a stola, while her standing figure symmetrically divides the relief composition into two parts. Her hands rest upon the heads of an ox (left) and a lion (right), which are the symbols of the legion VII Claudia (which was present at Viminacium during the entire Roman period) and the legion IV Flavia. Thus composed, the relief iconography demonstrates the ideological notion that the power and strength of the province of Moesia Superior relied on two military forces, which were responsible for its foundation. Based on the significance that the goddess Tyche had as the main protectress of a city, province or region during the 4th century, it would be justified to assume the worship of the protectress of Upper Moesia or Viminacium in this city until the year 441-443.

P(rovincia) M(oesia) S(uperior) COL(onia) VIM(inacium), while at the bottom, the local year of mintage is inscribed $A N$ (I-XVI). Борић-Брешковић 1976; БорићБрешковић 1986: 138-142; Душанић 1961: 141-143. Dušanić 1976: 53-58.

8 This coat of arms was found as spolia, built into the old structure in the village of Stari Kostolac. More about this finding in: Јацановић, Пиндић 1986, 61-64; СпасићЂурић 2002: 168, сл. 132; Спасић-Ђурић 2015, кат. 114.

\section{CONCLUSION}

The goddesses who were worshipped as protectresses of a city/metropolis (metropolis $\mu \eta ́ \tau \eta \rho \pi$ ó $1 \varsigma$ - mother city), were Athena, Artemis and Aphrodite/Venus (Greaves 2004: 27). During the period of Roman reign and especially in the Late Antiquity, this role was, however, characteristic of personifications such as Tyche and Fortuna, associated not only with large urban centres like Rome, Constantinople, Antioch, Alexandria or Trier, but also with smaller centres in Roman provinces. On the territory of the Central Balkans, such deities were also associated with regions i.e., lands, and among them were the Syrian goddess Dea Siria (whose cult is confirmed with two findings from the $1^{\text {st }}$ century $)^{9}$ and the Egyptian goddess Isis, who was assimilated with the Roman goddess Fortuna (whose cult is confirmed with three statues of the so-called Isis-Fortuna type) (Vulić1941-48: 92, бp. 199, 200; Zotović 1966: no 47, pl. XVI/1, no 49, pl. XVI/2.; Срејовић, Цермановић-Кузмановић 1987a: 102, кат. 42; Tomović 1992: 74, kat. 82, 105; Петровић, Јовановић 1977: 61, 62 кат. 5, 8; Дрча 2004: кат. 62; Lisičar 1961: 127-130).

The deification of the goddess Tyche-Fortuna, was developed owing to the popularity of these, predominantly politically oriented, personifications in Roman literature and art (Smith 2011: 119-122). The largest city of the Roman Empire, the unique Urbs, caput mundi, with its protectress Roma, not in a political context, but in accordance with the early Christian visual culture, had fallen under the shadow of New Rome, Constantinople (Grig 2012: 31-52). Similar situations in the cities within the Roman provinces of the Central Balkans can be explained not only with the ideal of Roma Aeterna, but also with the geographically-strategic positions of urban centres near the Danube Limes and the familiar atmosphere of the uncertainty of survival of the Greek polis(es), when the power-

9 More about the cult of Dea Siria and findings from Dolno Nerezi and Skopje in: Gavrilović 2010: 228-237. 
ful protective force of these deities was evoked (Beerden 2013: 208). Tyche-Fortuna was more powerful than other Greek or Roman personifications, since the fate of the city was in her hands, as genius loci, yet she was just a deity, not a goddess and, thus, did not have the characteristics of protection which saints or Theotokos would have during the Middle Ages (Bertelli 1999: 129-130). Therefore, at one point, the idea of the protection of this long worshiped deity was abandoned. Unlike the process of the gradual abandonment of pagan motifs or their transformation into Christian symbols, this cessation of the worship of Tyche-Fortune happened in the 5th century, before the powerful patroness of Christianity and Theotokos' cult, Empress Pulcheria (Herrin 2000: 14).

Theotokos became the main and only protectress of the capital city and the whole state, and her associations with the divine dimensions of Tyche are recognisable in the attributes of ancient goddesses, namely Tyche in Akathist Hymn, ${ }^{10}$ while in the visual culture of Constantinople, Tyche coexisted with Theotokos during the 5th and 6th centuries (Pentcheva 2010: 19-21).

\section{BIBLIOGRAPHY}

Анђелковић et al. - Анђелковић, Ј., Рогић, Д. и Николић, Е. 2013

Од венца до круне - развој идеје и значења у визуелној култури касне антике и раног хришћанства, Српска теологија данас 2012: 383-392.

\section{Baratte, F. 1978}

Lingots d'or et d'argent en rapport avec l'atelier de Sirmium, Sirmium VIII: 99-109.

10 The twenty forth verse of the Akathist Hymn praises many aspects of Theotokos' power, especially Her role of helping and protecting, which influenced the creation of Theotokos' image as protectress of the state and the emperor. More about metaphors that associate Theotokos and Tyche in: Pentcheva 2010: 12-21; On epithets associated with Theotokos in the Akathist Hymn see: Peltomaa 2011: 109-116.

\section{Beerden, K. 2013}

Worlds Full of Signs: Ancient Greek Divination in Context, Brill, Leiden.

\section{Bertelli, C. 1999}

Visual Images of the Town in Late Antiquity and the Early Middle Ages, in: The Idea and Ideal of the Town Between Late Antiquity and the Early Middle Ages, (eds.) G. P. Brogiolo, B. Ward-Perkins, Brill, Leiden: 127-146.

\section{Борић-Брешковић, Б. 1976}

Новаи колоније Виминаиијума, Збирка Светозара Сm. Душанића, Народни музеј Београд, Београд.

\section{Борић-Брешковић, Б.1986}

Реверсне представе на новцу колоније Виминацијума, Зборник радова Народног музеја у Београду, XII-1: 138-142.

\section{Dobruna-Salihu, E. 2013}

Votivna ara Deae Dardanicae i beneficijarna postaja iz Vendenisa, Vjesnik Arheoloskog muzeja u Zagrebu, Vol. 45, No.1 (2012): 217-224.

Дрча, С. 1993

Каталог, у: Римски изарски градови и палате у Србији, Д. Срејовић (ур.), Београд, САНУ.

\section{Дрча, С. 2004}

Каталог, у: Археолошко благо Ниша, од неолита до средњег века, Српска академија наука и уметности, Београд.

\section{Душанић, С. 1961}

Новац колоније Виминацијум и датуми из римске историје средине III века, I. Локална ера Виминацијума, Старинар 12: 141-143.

\section{Dušanić, S. 1976}

The Era of Viminacium, u: Kovanje i kovnice antičkog i srednjovekovnog novca, Materijali simpozijuma održanog 30.I.-1.II.1975.god. u Narod- 
nom muzeju Beograd, (ur.) V. Kondić, Beograd: $53-58$

\section{Greaves, A. M. 2004}

The Cult of Aphrodite in Miletos and its Colonies, Anatolian Studies, Vol. 54: 27-33.

\section{Grig, L. 2012}

Competing Capitals, Competing Representations: Late Antique Cityscapes in Words and Pictures, in: Two Romes: Rome and Constantinople in Late Antiquity, (eds.) L. Grig, G. Kelly, Oxford University Press, Oxford/New York: 31-52.

\section{Herrin, J. 2000}

The Imperial Feminine in Byzantium, Past and Present, No. 169: 3-35.

\section{Јацановић, Д. Пиндић, М. 1986}

Грб колоније Виминацијума - његова иконографска схема и значење, Viminacivm I: 61-64.

\section{Jeremić, M. 2009}

The Sirmium Imperial Palace Complex, in Light of the Recent Archaeological Investigations, in: Diocletian, Tetrarchy and Diocletian's Palace on the 1700 th Anniversary of Existence (International Conference, Split, September 2005, (eds.) N. Cambi, J. Belamarić and T. Marasović, Split: 471-499.

\section{Jovanović, A. 1980}

Прилог проучавању скулптура са Медијане, Нишки зборник 9: 53-60.

\section{Luyster, R. 1965}

Symbolic Elements in the Cult of Athena, History of Religions, Vol. 5, No. 1: 133-163.

Љубомировић, И. 2014

Резултати најновијих истраживања на Медијани, Теме 2: 733-745.
Марић, Р. 2003 (rp. 1933)

Антички култови у нашој земьи, Београд.

\section{Matheson, S. B. and Pollitt, J. J. 1994}

An obsession with Fortune: Tyche in Greek and Roman art, Yale University Art Gallery Bulletin, New Haven.

\section{McCown, C. C. 1931-32}

The Goddesses of Gerasa, Annual of the American Schools of Oriental Research, Vol. 13: 129-166.

\section{Mundell Mango, M. 1992}

The Purpose and Places of Byzantine silver stamping, in: Ecclesiastical Silver Plate in Sixth-Century Byzantium: Papers of the Symposium Held May 16-18, 1986, at the Walters Art Gallery, Baltimore and Dumbarton Oaks, Organized by Susan A. Boyd, Marlia Mundell Mango, and Gary Vikan, 3, (eds.) S. A. Boyd, M. Mundell Mango, Dumbarton Oaks, Washington, D.C. : 203-215.

Peltomaa, L. 2011

Epithets of the Theotokos in the Akathistos Hymn, in: The Cult of the Mother of God in Byzantium: Texts and Images, (eds.) L. Brubaker and M. B. Cunningham, Ashgate, Farnham: 109-116.

\section{Pentcheva, B.2010}

Icons and Power: The Mother of God in Byzantium, Pennsylvania State University Press, University Park, PA.

Petković et al. - Petković, S., Tapavički-Ilić, M. and Anđelković Grašar, J. 2015A

Portrait Oil Lamp from Pontes - Possible Interpretations and Meanings within Early Byzantine Visual Culture, Starinar 65: 79-89.

\section{Петровић, П. 1993}

Naissus - задужбина цара Константина, у: Римски иарски градови и палате у Србији, (ур.) Д. Срејовић, САНУ, Београд: 55-81. 


\section{Петровић, П. и Јовановић, С. 1997}

Културно благо књажевачког краја, археологија, Археолошки институт у Београду, Завичајни музеј у Књажевцу, Београд.

\section{Popović, I. 2008}

Marble Sculptures from the Imperial Palace in Sirmium, Starinar 56: 153-166.

\section{Поповић, И. 2008}

Dea Dardanica из Медијане и сродни споменици из балканских провинција Царства, Ниш и Византија VI: 31-43.

\section{Popović, I. 2009a}

Les sculptures du palais imperial de Sirmium (fouilles 2003-2005), in: Les ateliers de sculpture réginoaux: techniques, styles et iconographie, Actes $d u$ Xe Colloque international sur l'art provincial romain, Arles et Aix-en-Provence 2009a: 267-272.

\section{Popović, I. 2009b}

Sirmium, in: Lexicon Iconographicum Mythologiae Classicae (LIMC). Supplementum 2, Düsseldorf: 452.

\section{Popović, I. 2012}

Sirmium: mermerne skulpture (Sirmium: marble sculptures), Arheološki institut, Beograd, Blago Sirmijuma, Sremska Mitrovica.

Smith, A. C. 2011

Polis and Personification in Classical Athenian Art, Brill, Leiden.

\section{Спасић-Ђурић, Д. 2002}

Виминацијум, главни град римске провинције Горње Мезије, Народни музеј Пожаревац, Пожаревац.

\section{Спасић-Ђурић, Д. 2015}

Град Виминаиијум, Народни музеј Пожаревац, Пожаревац.
Срејовић, Д. и Цермановић-Кузмановић А. 1987

Римска скулптура у Србији, Српска академија наука и уметности, Београд 1987.

\section{Tomović, M. 1992}

Roman Sculpture in Upper Moesia, Monographies No.24, Archaeological Institute, Beograd.

\section{Toynbee, J.M.C 1947}

Roma and Constantinopolis in Late-Antique Art from 312-365, The Journal of Roman Studies, Vol. 37, Parts 1 and 2: 135-144.

\section{Васић, М. 2013}

Градови и царске виле у римским провинцијама на тероторији данашње Србије, у: Константин Велики и Милански едикт 313.: рађање хришћанства у римским провинцијама на тлу Србије, (ур.) И. Поповић, Б. Борић-Брешковић, Народни музеј, Београд: 76-101.

\section{Vulić, N. 1941-1948}

Antički spomenici naše zemlje, Spomenik SAN

XCVIII, Beograd. 
REZIME

ŽENSKA MOĆ KOJA ŠTITI:

KO JE ŽENA KOJA BDI NAD

GRADOM? BOGINJE ZAŠTITNICE

NA TERITORIJI CENTRALNOG

BALKANA U PERIODU KASNE

ANTIKE

KLJUČNE REČI: BOGINJE ZAŠTITNICE, TIHE, FORTUNA, CENTRALNI BALKAN, KASNA ANTIKA.

Različite boginje grčkog porekla, poput Atene, Artemide, Afrodite ili Nemeze, a potom i njihovi rimski ekvivalenti, među svojim funkcijama imale su i one koje se tiču zaštite gradova i njihovog stanovništva. Ovde spadaju i boginje istočnjačkog porekla poput Izide i Kibele. U kasnoantičko vreme najpoznatije zaštitnice gradova bile su grčka Tihe i rimska Fortuna, odnosno boginje čija se zaštita odnosi i na provincije ili pak oblasti. U vizuelnoj kulturi kasnoantičkog perioda pored nekadašnje, najvažnije zaštitnice Rima, dominirajuću ulogu stiču i zaštitnice gradova poput Trira, Aleksandrije, Antiohije, te ponajviše novoosnovane prestonice Konstantinopolja. Na prostoru centralnog Balkana, sa njima korespondiraju Tihe Sirmijuma, Naisa, Viminacijuma... Ovakva situacija odgovara pogledu provincijskih gradova prema najvažnijem uzoru - Rimu, ali može biti objašnjena i istorijskim okolnostima, koje podrazumevaju stalne upade varvara na ove prostore, te želju i potrebu stanovništva centralnog Balkana za uspešno vođstvo i zaštitu boginja koje će brinuti o sudbini grada ili zemlje na kojoj žive. Prekid u poštovanju Tihe kao zaštitnice grada, odgovara širenju Bogorodičinog kulta, te je od 5. veka Bogorodica preuzela ove funkcije i postala najvažnija zaštitnica grada, najpre Konstantinopolja. 